\title{
Description of bone mineral density in postmenopausal women at Immunoendocrinology Integrated Laboratory, Faculty of Medicine University of Indonesia
}

\author{
D.S. Wibisono, A. Baziad
}

\begin{abstract}
Abstrak
Untuk mengetahui pola densitas mineral tulang pada wanita pasca menopause dilakukan penelitian secara retrospektif terhadap 40 wanita pasca menopause dengan menggunakan alat Dexa pada tulang $L_{2}-L_{4}$. Didapatkan hasil dengan akurasi formula survey $15 \%$ : rerata usia menopause 53,25 tahun, 30 \% densitas mineral tulang normal, 52,5\% osteopenia \& 17,5\% osteoporosis. Pada penelitian ini juga didapatkan ada hubungan yang kuat $(r=0,547) \&$ sangat bermakna $(p=0,000)$ antara tinggi badan dengan densitas mineral tulang, didapatkan hubungan yang cukup $(r=0,315) \&$ bermakna $(p=0,047)$ antara berat badan dengan densitas mineral tulang, demikian pula hubungan yang cukup $(r=-0,301) \&$ bermakna $(p=0,059)$ antara lama menopause dengan densitas mineral tulang, serta tidak didapatkan hubungan antara usia $(r=0,119)$ maupun Indeks Masa Tubuh $($ IMT $)(r=0,086)$ dengan densitas mineral tulang. (Med J Indones 2004; 13: 31-9)
\end{abstract}

\begin{abstract}
To identify the pattern of bone mineral density in postmenopausal women through retrospective study in 40 postmenopausal women using Dexa instrument in bones (L2 - L4). Results with $15 \%$ of survey formula accuracy were found: mean of menopausal age was 53.25 years, normal bone mineral density 30\%, osteopenia 52.5\%, and osteoporosis $17.5 \%$. A very strong relationship ( $r=0.547)$ and a significant relationship $(p=0.000)$ between body height and bone mineral density were found in this study, and there was a moderate $(r=0.315)$ and significant $(p=0.047)$ relationship between body weight and bone mineral density, and likewise there was a moderate $(r=-$ $0.301)$ and significant $(p=0.059)$ relationship between duration of menopause and bone mineral density. By contrast, no relationship was found between age $(r=0.119)$ and Body Mass Index (BMI) ( $r=0.086)$ and bone mineral density. (Med J Indones 2004; 13: 31-9)
\end{abstract}

Keywords: Duration of menopause, menopause age, body height, body weight, body mass index, and bone mass density.

It was estimated that by the year 2000, life expectancy rate of Indonesian women reached 67.5 years, and the group of elderly people reached $8.2 \%$ of all Indonesian population. ${ }^{1}$

Physiologically, estrogen begins to decrease at the age of 40 years and is at the lowest level at the age of 53 years. The decrease of estrogen will result in the decrease of osteoblast activity and form type I collagen. Bone formation decreases physiologically, and the changes in the remodeling balance of the bone to bone resorption will occur. ${ }^{1}$

Department of Obstetrics and Gynecology, Faculty of Medicine University of Indonesia / Dr. Cipto Mangunkusumo Hospital, Jakarta, Indonesia
Estrogen triggers osteoblast activity and bone formation occurs, and when estrogen decreases bone deformation will occur leading eventually to bone fragility. This condition will result in the postmenopausal disorder of osteoporosis at the risk of bone fractures.

Data from the US showed that of 25 million people of the US population suffering from osteoporosis, $80 \%$ were women among whom 1.5 million people experienced fractures each year and 0.5 million people had thoracal and lumbal vertebral fractures which frequently resulted in deformity and hunched posture. $^{2}$

World Health Organization (WHO) defines osteoporosis as a disease characterized by the decrease of bone mass and bone micro-architecture damage, a condition 
which will contribute to bone fragility resulting in the increased risk of bone fractures. ${ }^{2,4,10,11}$

According to WHO, osteoporosis occurs when bone mineral density (BMD) is greater than 2.5 of Standard Deviation under the mean of young adult. ${ }^{4}$

Table 1. WHO: Criteria of Osteoporosis in Women ${ }^{4,7,11}$

\begin{tabular}{ll}
\hline \multicolumn{1}{c}{ Category } & \multicolumn{1}{c}{ Criteria } \\
\hline Normal & $\begin{array}{l}\text { BMD }<1 \text { of SD under the mean } \\
\text { of young adult. } \\
\text { BMD 1 }-2.5 \text { of SD under the } \\
\text { Osteopenia }\end{array}$ \\
Osteoporosis & $\begin{array}{l}\text { BMD }>2,5 \text { SD under the mean } \\
\text { of healthy young women } \\
\text { BMD }>2.5 \text { of SD under the mean } \\
\text { of healthy young women and there } \\
\text { is one or more bone fractures }\end{array}$ \\
\hline
\end{tabular}

The objective of this study is to identify the pattern of bone mineral density in post-menopausal women and specifically to assess the presence or absence of the relationship between body height, body weight, age and duration of menopause with bone mineral density

\section{METHODS}

This retrospective analytical study was conducted at Immuno-endocrinology Integrated Makmal Laboratory - Faculty of Medicine University of Indonesia, on the basis of the medical records of Immuno-endocrinology Integrated Makmal Laboratory - Faculty of Medicine University of Indonesia from November 1, 2001 to November 30, 2001.

Post-menopausal women undergoing bone density using Dexa instrument in bones $\mathrm{L}_{2}-\mathrm{L}_{4}$ were included in this study. Statistical analysis was performed with SPSS using one sample statistics, paired sample correlation and coefficient relationships were considered significant if $\mathrm{p}<0,05$.

\section{Operational definition}

Bone mineral density (BMD) is the amount of mineral (gram) per centimeter of bone quadrate, obtained from the measurement with Lunar DPX dual energy X-ray Densitometry (Lunar Corporation, Madison, Wisconsin, USA).

\section{WHO Criteria}

Normal :

BMD $<-1$ SD of the mean of young adult

Osteopenia :

BMD - 1 SD - - 2.5 of DS of the mean of young women

Osteoporosis :

$\mathrm{BMD}>-2.5 \mathrm{SD}$ under the mean of young women

T Score :

What is SD above and under BMD at young age

Z Score :

Patient's BMD was compared with her age and gender in SD

Menopause is :

The last menstruation which is still controlled by the function of ovarian hormone.

Post-menopause is :

Ammenorrhea in 12 months after menopause characterized by high level of LH and FSH, and low level of estrogen and progesterone.

\section{RESULTS}

The study was conducted retrospectively in 40 menopausal patients, and the results found are presented in Table 2 .

Table 2. Clinical characteristics of studied cases

\begin{tabular}{lcc}
\hline \multicolumn{1}{c}{ Characteristics } & Mean & $\begin{array}{c}\text { Standard } \\
\text { Deviation }\end{array}$ \\
\hline Age (year) & 53.25 & 3.48 \\
Body height (cm) & 154.98 & 5.08 \\
Body weight (Kg) & 60.10 & 9.43 \\
Menopause (Year) & 3.95 & 2.43 \\
BMD & 0.94782 & 0.12140 \\
T-Score & -1.43 & 1.01 \\
Z-Score & -0.91 & 2.39 \\
Body Mass Index & 24.9950 & 3.5266 \\
(BMI= BW/BH $\left.{ }^{2}, \mathrm{Kg} / \mathrm{Cm}^{2}\right)$ & & \\
\hline
\end{tabular}

Table 2 shows that mean post-menopausal patients' ages was 53.25 years in which the youngest age was 47 years and the oldest 62 years.

Patients' body height has a range of $145 \mathrm{~cm}$ to $166 \mathrm{~cm}$ and mean body height was $154.98 \mathrm{~cm}$. Range of patients' body weight was between $40 \mathrm{~kg}$ and $83 \mathrm{~kg}$ with a mean of $60.10 \mathrm{~kg}$. Duration of menopause started from 1 year to 10 years after menopause with a mean of 3.95 years.

Of 40 post-menopausal cases studied mean BMD was found to be 0.94782 and mean T-Score was 1.43. 


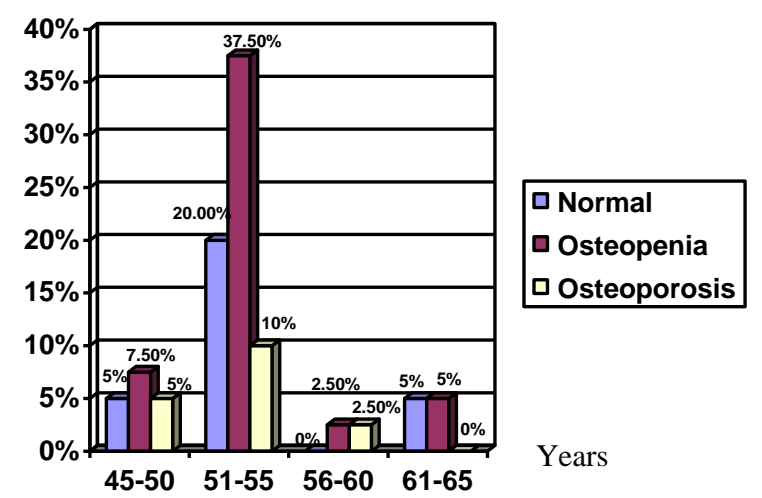

Figure 1. Correlation between age and percentage of normal cases and BMD decrease

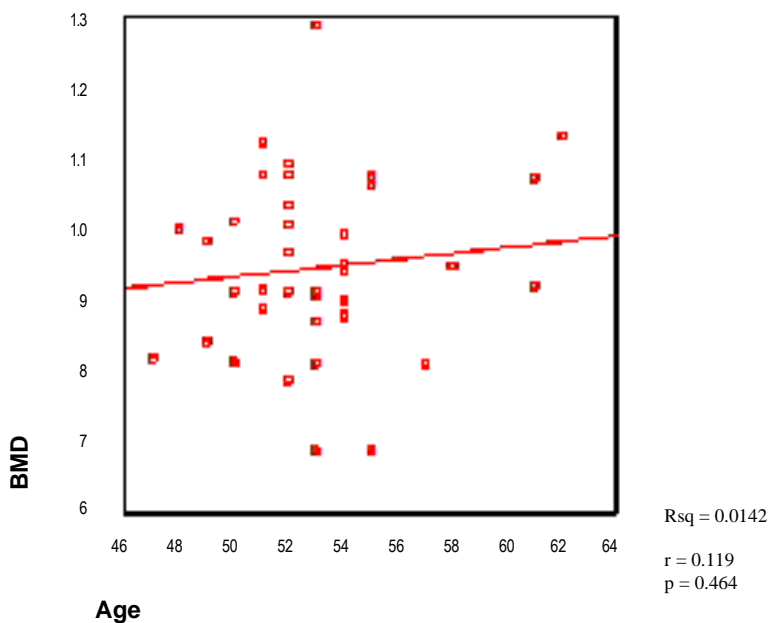

Figure 2. Correlation between age and BMD

Table 3 shows that there were 12 patients $(30 \%)$ with normal bone mineral density, 21 patients $(52.5 \%$ with osteopenia and 7 pateints (17.5\%) with osteoporosis such that there were $70 \%$ of patients experiencing bone mineral density decrease lower than 1 SD.

Figure 1 shows that the highest frequencies of osteopenia (37.5\%) and osteoporosis (10\%) were
Table 3. Correlation between age and number of normal cases and BMD decrease

\begin{tabular}{cccc}
\hline Age & $\begin{array}{c}\text { Normal } \\
<-1 \text { SD }\end{array}$ & $\begin{array}{c}\text { Osteopenia } \\
-1 \text { SD }-2,5 \text { SD }\end{array}$ & $\begin{array}{c}\text { Osteoporosis } \\
>-2,5 \text { SD }\end{array}$ \\
\hline $45-50$ & 2 & 3 & 2 \\
$51-55$ & 8 & 15 & 4 \\
$56-60$ & 0 & 1 & 1 \\
$61-65$ & 2 & 2 & 0 \\
\hline Total & 12 & 21 & 7 \\
\hline & $30 \%$ & $52.5 \%$ & $17.5 \%$ \\
\hline
\end{tabular}

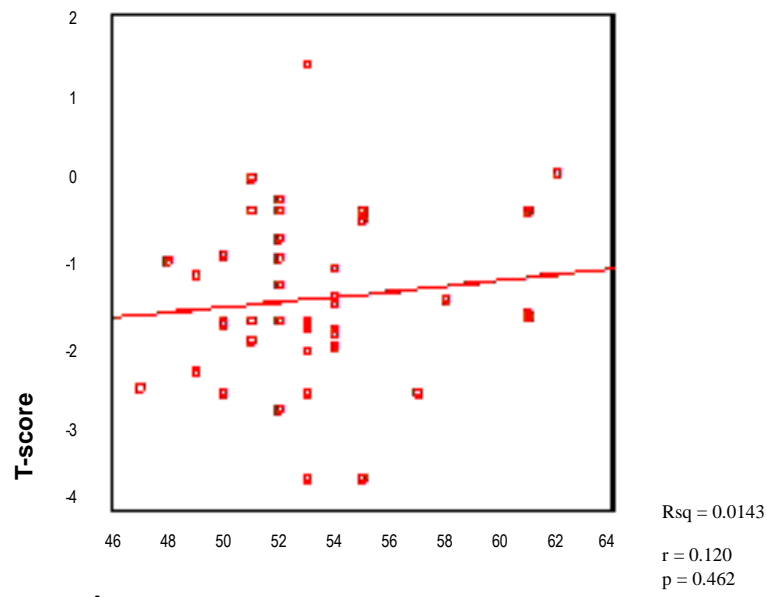

Age

Figure 3. Correlation between age and T-Score

found at the age of 51-55 years. . It is evident from Figures 2 and 3 that BMD and T-Score were determined by age factor at $1 \%$ (Rsq $=0.0142$ and 0.0143 ).

Figures 2 and 3 also demonstrate a weak relationship between age and BMD $(r=0.119)$ and age and T-Score $(r=0.120)$, and both relationships were not significant ( $\mathrm{p}>0.05)$. 


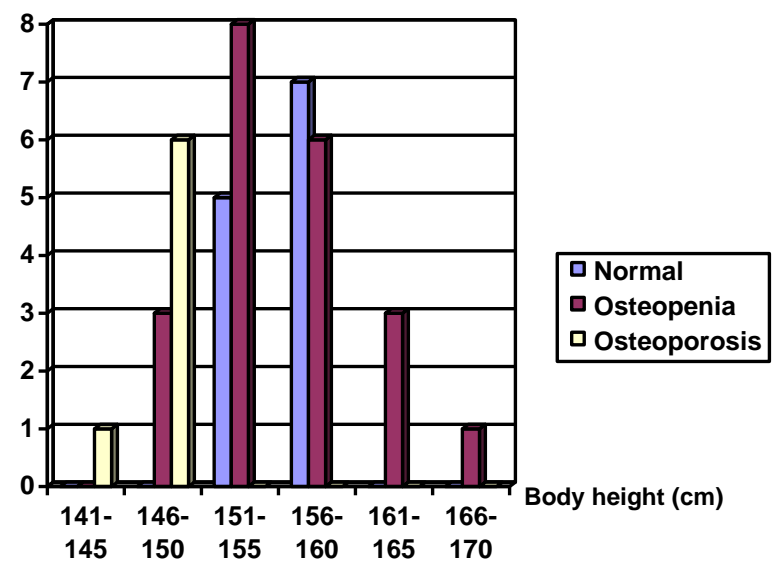

Figure 4. Correlation between body height and number of normal cases and BMD decrease

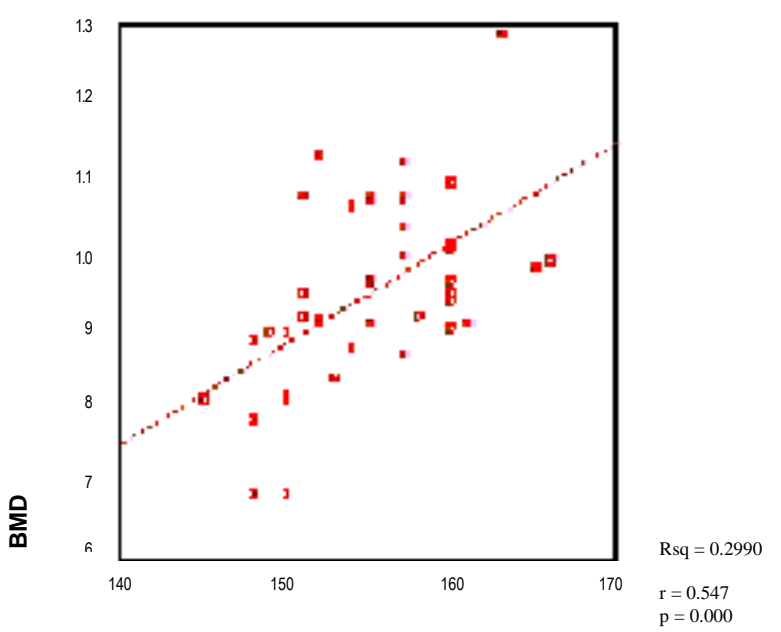

Body Height (cm)

Figure 5. Correlation between body height and BMD

In the correlation between body height and T-Score, it appears that osteopenia had the highest frequency in body height of 151-155 cm, while osteoporosis occurred most frequently in body height of 146-150 $\mathrm{cm}$, and the higher the body weight the lower the incidence rate of osteopenia. (Figure 4 and Table 4 ).

Figures 5 and 6 demonstrate a strong correlation $(\mathrm{r}=$ 0,547 ) between body height and bone mineral density,
Table 4. Correlation between Body Height and number of normal cases and BMD decrease

\begin{tabular}{cccc}
\hline $\begin{array}{c}\text { Body } \\
\text { Height }\end{array}$ & $\begin{array}{c}\text { Normal } \\
<-1 \text { SD }\end{array}$ & $\begin{array}{c}\text { Osteopenia } \\
-1 \text { SD }-2,5 \text { SD }\end{array}$ & $\begin{array}{c}\text { Osteoporosis } \\
>-2,5 \text { SD }\end{array}$ \\
\hline $141-145$ & 0 & 0 & 1 \\
$146-150$ & 0 & 3 & 6 \\
$151-155$ & 5 & 8 & 0 \\
$156-160$ & 7 & 6 & 0 \\
$161-165$ & 0 & 3 & 0 \\
$166-170$ & 0 & 1 & 0 \\
\hline Total & 12 & 21 & 7 \\
\hline
\end{tabular}

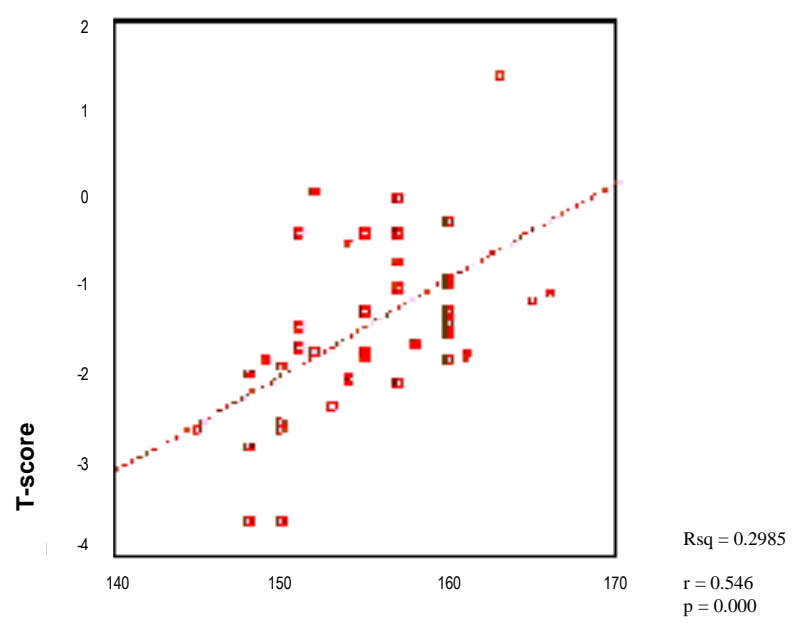

Body Height (cm)

Figure 6. Correlation between body height and T-Score

and this correlation was very significant $(\mathrm{p}<0.01)$. Likewise, there was a strong correlation between body height and T-Score. $(r=0.546)$ and $(p<0.01)$.

From Figures 5 and 6, it is evident that bone mineral density and T-Score were determined by body height by $29 \%$ ( Rsq $=0.2990$ and 0.2995 ). 

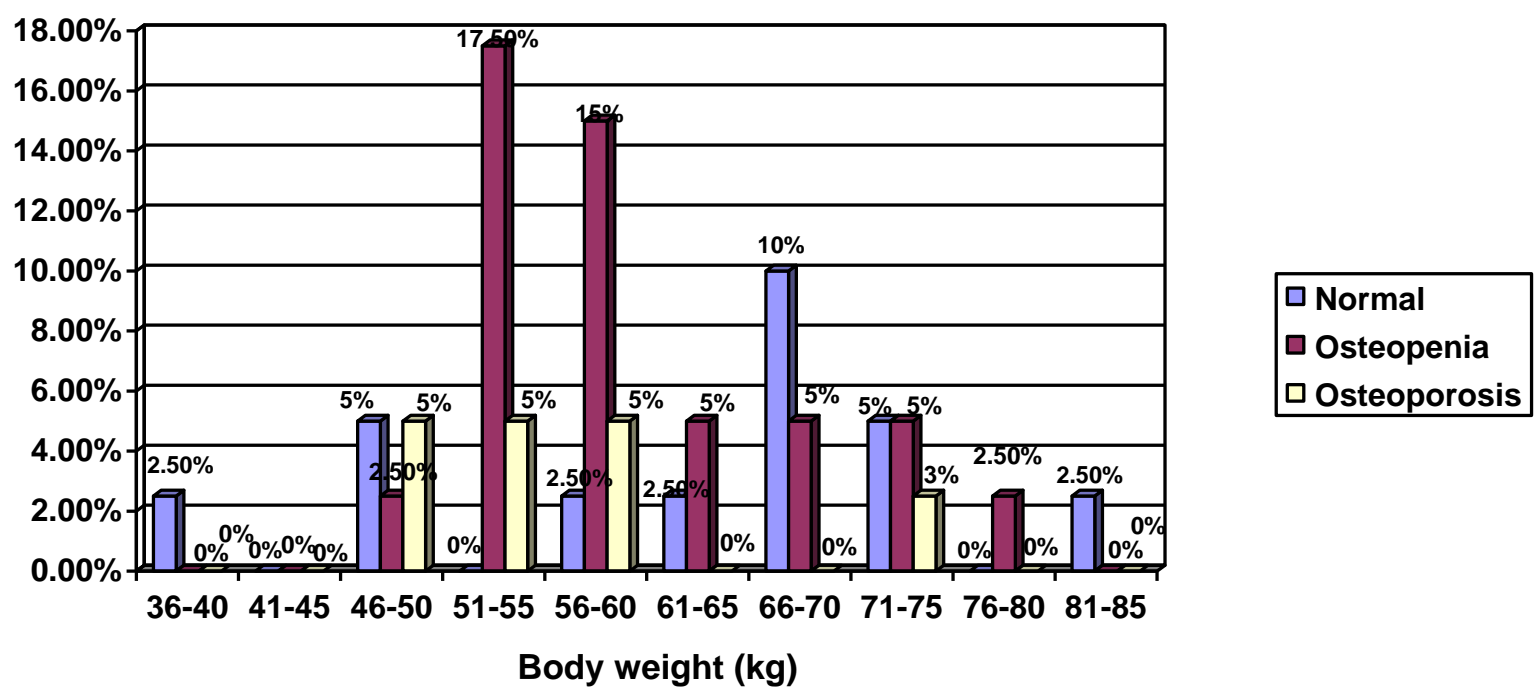

Figure 7. Correlation between body weight and percentage of normal cases and BMD decrease

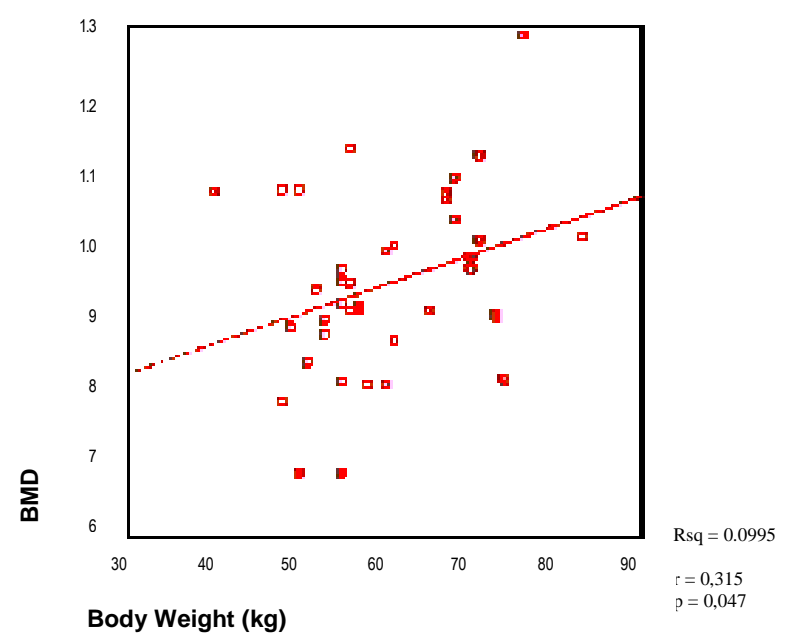

Figure 8. Correlation between body weight and - BMD

The correlation between body weight and T-Score is evident in Figure 7. Osteopenia had the highest frequency in body weight of 51-55 $\mathrm{kg}(17.5 \%)$ and body weight of $56-60 \mathrm{~kg}(15 \%)$, while osteoporosis occurred most frequently in body weight of $46-50 \mathrm{~kg}$, $51-55 \mathrm{~kg}$ and $56-60 \mathrm{~kg}$ (each was $5 \%$ respectively).

On statistical analysis, a moderate $(\mathrm{r}=0.315)$ and significant $(\mathrm{p}<0.05)$ correlation was found between body weight and body mineral density (Figure 8 ).

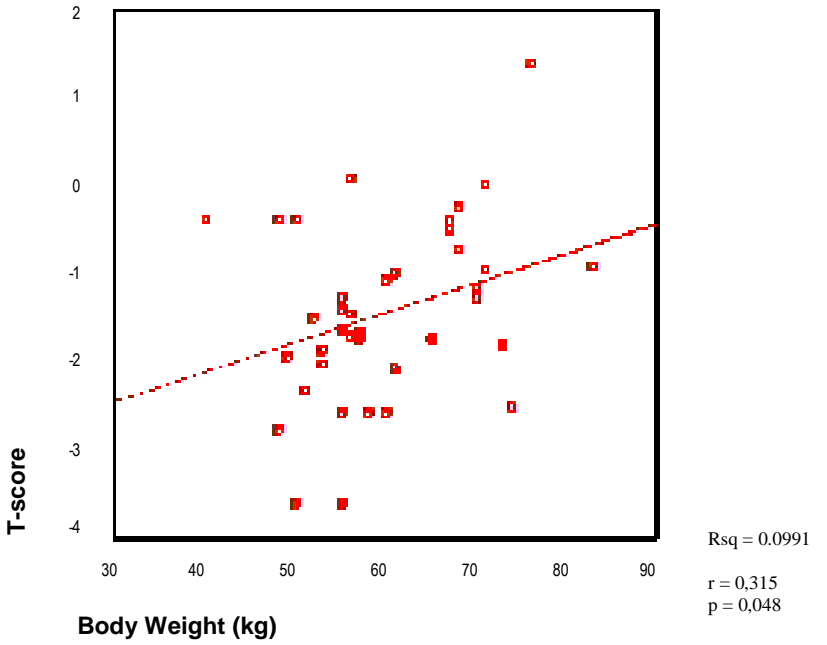

Figure 9. Correlation between body weight-T-Score

Likewise, there was a moderate $(\mathrm{r}=0.315)$ and significant $(\mathrm{p}<0.05)$ correlation between body weight and $\mathrm{T}$-Score.

From Figures 8 and 9 it is evident that body mineral density and T-Score were determine by body weight factor by $9 \%$. ( Rsq = 0,0995 \& 0,0991 ). 


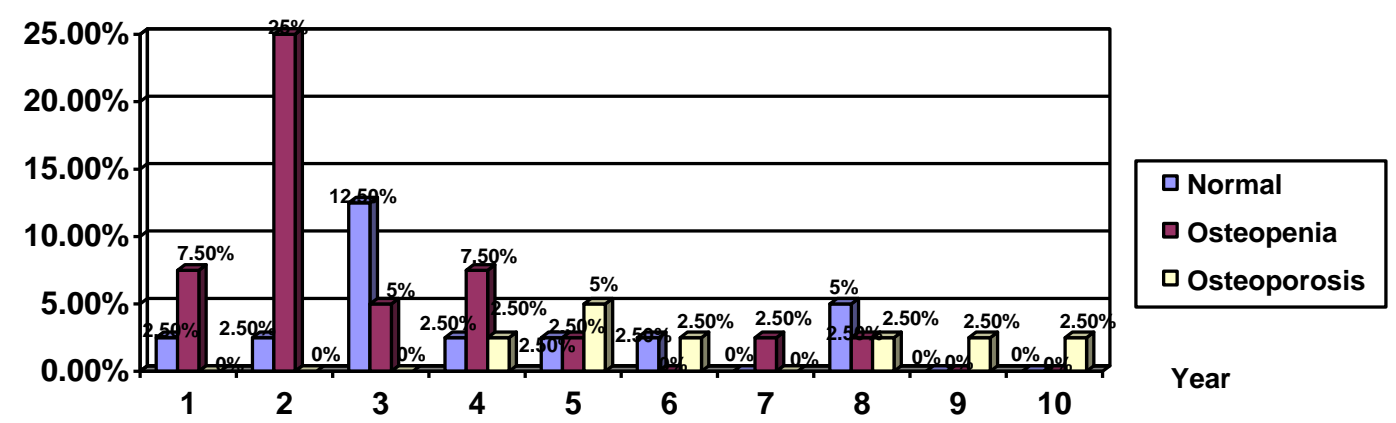

Figure 10. Correlation between duration of menopause and percentage of normal cases and BMD decrease

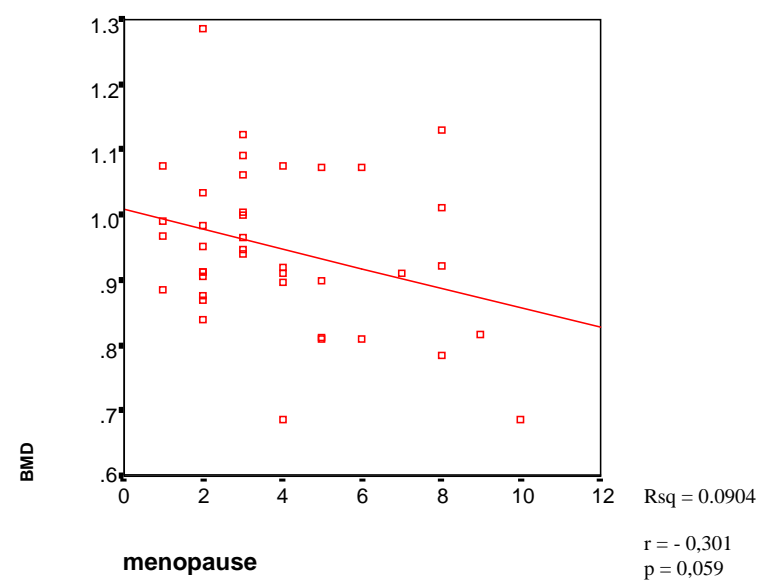

Figure 11. Correlation between duration of menopause and $B M D$

In terms of duration of menopause and T-Score, it shows that osteopenia had the highest frequency in duration of menopause of 2 years $(25 \%)$, and osteoporosis occurred most frequently after 5 years of menopause (5\%) (Figure 10). A moderate correlation was found between duration of menopause and bone mineral density $(\mathrm{R}=-0.301)$; however, this relationship was not significant $(\mathrm{p}>0.05)$ (Figure 11). Likewise, there was a moderate correlation between duration of menopause and T-Score $(r=-0.301)$, yet

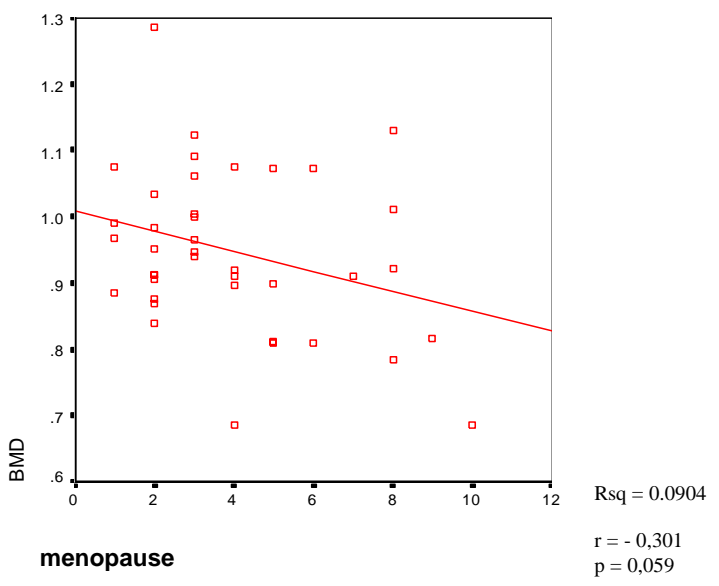

Figure 12. Correlation between duration of menopause and T-Score

this relationship was not significant as well $(\mathrm{p}>0.05)$ (Figure 12).

From Figures 11 and 12 it is evident that body mineral density and T-Score were determined by duration of menopause factor by $9 \%$ (Rsq= 0.0904 and 0.0903). By controlling other variant factors affecting body mineral density, it proved that the relationship between duration of menopause and body mineral density was significant $(\mathrm{p}=0.040)(<0.05)$. (See Table 5). 
Table 5. Multiple regression statistical analysis

\begin{tabular}{|c|c|c|c|c|c|}
\hline \multirow[b]{2}{*}{ Model } & \multicolumn{2}{|c|}{$\begin{array}{l}\text { Non-standardized } \\
\text { coefficients }\end{array}$} & \multirow{2}{*}{$\begin{array}{c}\text { Standardized } \\
\text { coefficient }\end{array}$} & \multirow[b]{2}{*}{$\mathrm{t}$} & \multirow[b]{2}{*}{$\mathrm{p}$} \\
\hline & B & Std. Error & & & \\
\hline $\begin{array}{ll}1 & \text { (Constant) } \\
& \text { menopause } \\
\text { BMI }\end{array}$ & $\begin{array}{l}-2.047 \\
-.141 \\
4.675\end{array}$ & $\begin{array}{l}1.118 \\
.066 \\
4.551\end{array}$ & $\begin{array}{l}-.338 \\
.163\end{array}$ & $\begin{array}{c}-1.831 \\
-2.128 \\
1.027\end{array}$ & $\begin{array}{l}.075 \\
.040 \\
.311\end{array}$ \\
\hline
\end{tabular}

a. Dependent variables : T-Score

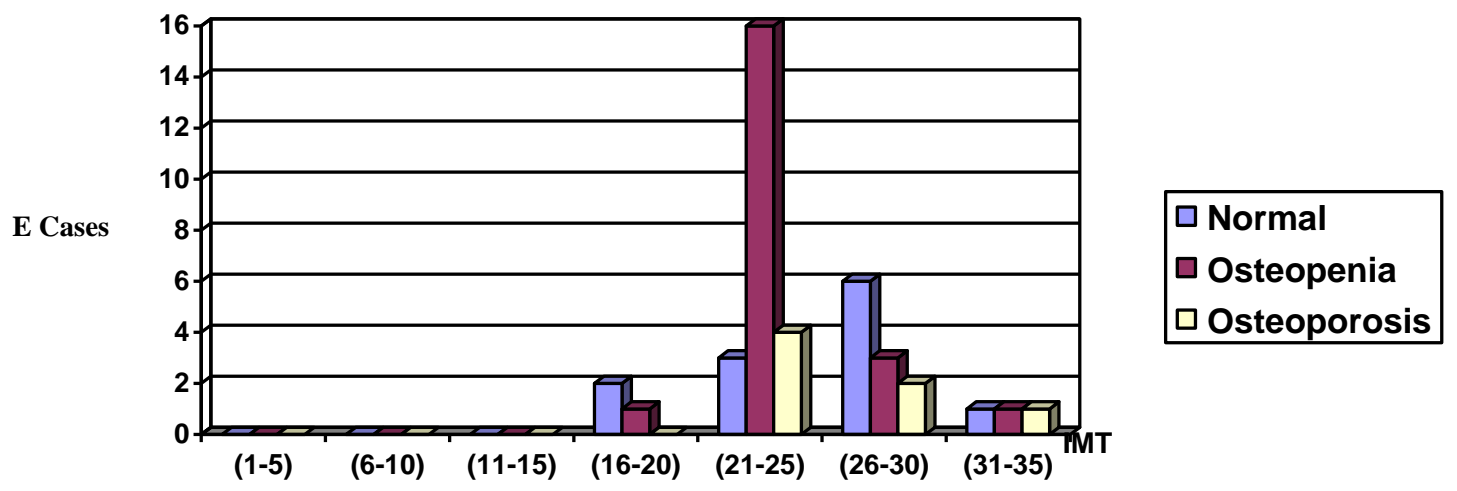

Figure 13. Correlation between BMI and number of normal cases and BMD decrease

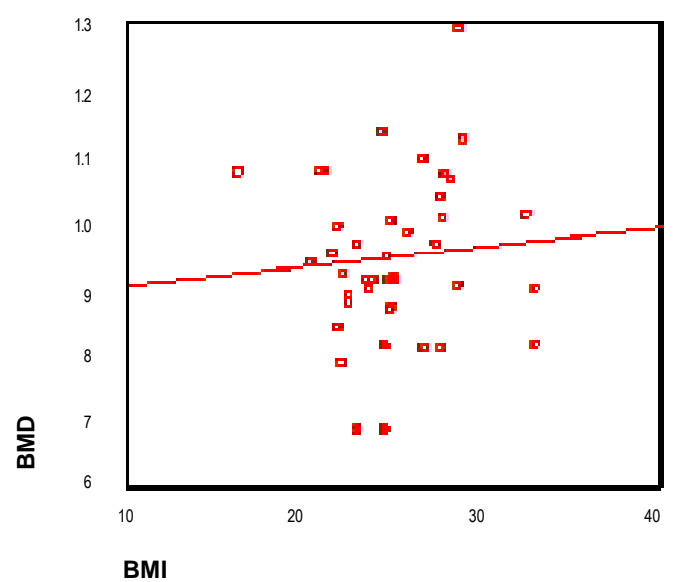

Figure 14. Correlation between BMI (Body Mass Index) and $B M D$

In the correlation between Body Mass Index and TScore, it was found that the highest incidence rate of osteopenia and osteoporosis occurred in Body Mass Index between 21-25 (Figure 13). On statistical

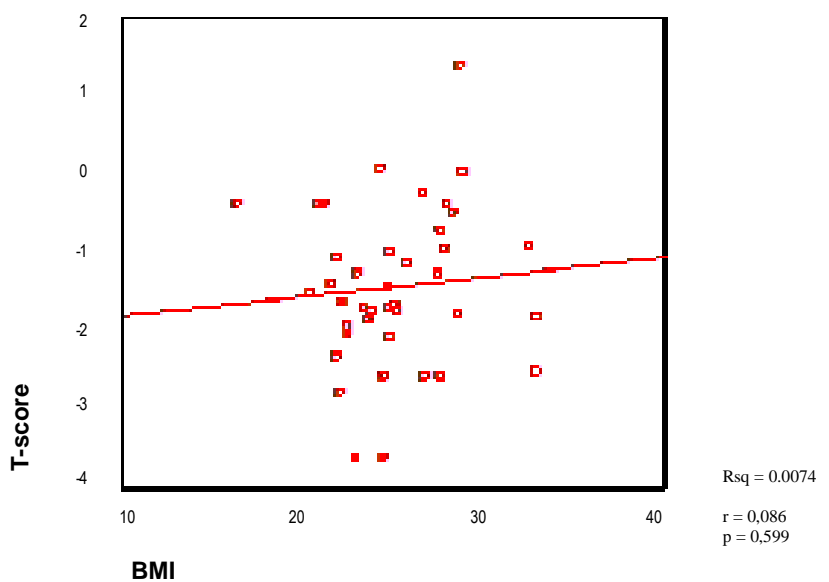

Figure 15. Correlation between BMI (Body Mass Index) and T-Score

analysis, it shows that the relationship of Body Mass Index and body mineral density and T-Score was weak ( $\mathrm{r}=0.086$ and $\mathrm{r}=0.086)$ and not significant $(\mathrm{p}=0.597$ and $\mathrm{p}=0.599)(>0.05)$. 


\section{DISCUSSION}

Of 40 post-menopausal patients with duration of menopause of 1 year to 10 years, it was found that mean menopausal age was 53.25 years. This finding was not different from the results of the previous studies $^{1,2 .}$ Of these 40 patients, $30 \%$ of patients had normal bone mineral density, $52.5 \%$ had osteopenia and $17.5 \%$ had osteoporosis. At first glimpse, these results would show a strong and significant relationship between estrogen deficiency (menopause) and the decrease of bone mineral density. However, in further examination the relationship between duration of menopause and bone mineral density proved moderate $(\mathrm{r}=-0.301)$ and not significant $(\mathrm{p}=0.059)$, as presented in Figures 11 and 12.

As known, estrogen produced during the reproduction period plays a role in the formation of bone cells and inhibits the resorption of bone cells in the remodeling process of the bone. $1,2,3,5,6,8,13,14$

In entering menopausal age in which there is a estrogen deficiency, it is understandable that a decrease of mineral bone density will occur in accordance with the duration of menopause. Nevertheless, in this study this correlation was not significant ( $p>0.05)$. This may be due to the fact that bone mineral density after menopause is determined not only by ovarian estrogen deficiency, but also by extra-ovarian estrogen such as fat and adrenal, as well as dietary food commonly consumed by Indonesian people and Asians in general, such as soybean cake (tempe), tofu, and soybean which can maintain and even enhance bone mineral density after menopause. ${ }^{12}$ In addition, physical activities and genetic factor may affect bone mineral density. ${ }^{13,14}$

Such foods contain a great deal of phytoestrogen (Isoflavon) which may increase bone mass density in the lumbal region, but not in other skeletal region. ${ }^{12}$

Another phytoestrogen, i.e. Daedzein is able to inhibit osteoclast activation. ${ }^{12}$ Geinstein is also able to increase IGF $\beta$ in vitro, i.e., a cytokine which causes osteoclast apoptosis. ${ }^{12}$.

In further study with statistical analysis of the 40 patients by controlling other variant factors affecting bone mineral density, it proved that duration of menopause has a significant correlation with bone mineral density $(\mathrm{p}=0.04)$. The difference in significance may be attributed to the fact that this study was retrospective in which the variants were not controlled.
The study on age and bone mineral density showed a weak $(r=0.119)$ and insignificant $(p=0.464)$ relationship. In fact, it has been understood that the peak of bone mass formation in women occurs at the age of 30 years, and after that a decrease in bone mineral density of $0.5-1 \%$ per year will follow ${ }^{2,8}$ and this decrease is even more noticeable when a woman enters menopausal age in which an estrogen deficiency (ovarian estrogen is not produced any longer) of 2 $3 \%$ per year will occur. ${ }^{2,8}$

However, menopausal age varies from woman to woman such that the results of this study showed a weak and insignificant correlation between woman age and bone mineral density. This result is evident from statistical analysis in Figures 2 and 3 in which bone mineral density and T-Score were determined by age factor by only $1 \%$ (Rsq=0.0142 and 0.0143 ). Nevertheless, given the frequency in the decrease of bone mineral density in menopausal age was $70 \%$ below - 1 DS, in which $52.5 \%$ was osteopenia and $17.5 \%$ osteoporosis after reaching menopausal age (Table 3), as if there was a correlation between age and bone mineral density. The highest frequency of osteopenia (37.5\%) and osteoporosis (10\%) occurred in the age range of $51-55$ years. In terms of the relationship of body mass index (BMI) and bone mineral density ( $\mathrm{T}$-Score), the highest frequency was found in BMI of 21 - 25, i.e., osteopenia in 16 cases and osteoporosis in 4 cases (Figure 13).

It also evident that in BMI > 25 (obesity), there was a tendency of decreased frequency of osteopenia and osteoporosis. This finding was in accordance with the condition of obese people who produce extra ovarian estrogen, such that bone mass density can still be maintained.

On statistical analysis, there was a weak $(r=0.086)$ and insignificant ( $>0.05)$ relationship between BMI and bone mineral density and T-Score (Figures 14 and 15). This may be due to the fact that this study was retrospective and the number of cases was less. The accuracy value in this study according to the survey formula was only $15 \%(\mathrm{~d}=0.15495)$.

In this study, there was a strong $(r=0.547)$ and very significant $(\mathrm{p}<0.01)$ relationship between body height and bone mineral density in post-menopausal women (Figures 5 and 6). Figure 4 shows that the higher the patient's body, the lower the incidence rate of osteopenia and osteoporosis, as explained by the load received by the bones. ${ }^{2}$ The higher the body, the 
weightier the load received by the bones, such that bone mass formation during premenopause at the peak period with appropriate nutrition ${ }^{2}$ may be a saving for post-menopause. ${ }^{1,2,3,14,15,16}$ This condition will provide concrete results in female workers with high posture and abundant physical activities. ${ }^{1,2}$

The study on body weight and bone mineral density in post-menopausal women also demonstrated a moderate $(\mathrm{r}=0.315)$ and significant $(\mathrm{p}<0.05)$ correlation. Likewise, there was strong $(r=3.15)$ and significant $(\mathrm{p}<0.05)$ relationship between body weight and TScore (Figures 8 and 9).

Several literatures ${ }^{13,14,15,16}$ demonstrated that extra ovarian estrogens such as fat, liver, and kidney are able to change androgen to estrogen through aromatization, and this can affect bone mineral density in post-menopausal women. In obese women, such changes were greater than in slim women, such that the incidence rate of osteoporosis in obese women after menopause was lower than in slim woman ${ }^{16 .}$ This finding was evident in Figure 7, in which the greater the patient's body weight, the lower the incidence rate of osteopenia and osteoporosis. The high incidence rate of osteopenia occurred in body weight of $51-60 \mathrm{~kg}$ (22.5\%), while that of osteoporosis occurred in body weight of $46-60 \mathrm{~kg}(15 \%)$.

\section{CONCLUSIONS AND RECOMMENDATION}

\section{Conclusions:}

With survey formula accuracy of $15 \%$, it was found that:

1. Mean menopausal age was 53.25 years

2. The incidence of bone mineral density (BMD) $>-1 \mathrm{SD}$ between 1 year and 10 years after menopause was $70 \%$, i.e. $52.5 \%$ osteopenia and $17.5 \%$ osteoporosis.

3. There was a strong correlation and very significant between body height and bone mineral density (BMD).

4. There was a moderate and significant correlation between body weight and bone mineral density (BMD).

5. There was a moderate and significant correlation between duration of menopause and bone mineral density (BMD), after other variant factors were controlled.

6. No correlation (weak correlation) was found between age or body mass index (BMI) and bone mineral density (BMD).
Recommendation:

A similar study with a greater number of cases and a more selective and multicenter study throughout Indonesia should be conducted.

\section{REFERENCES}

1. Rachman IA. Paparan sinar ultraviolet Beta terhadap remodeling tulang : studi eksperimen pada macaca fascicularis yang hipoestrogenik, (disertasi) Jakarta FKUI, 1999: 1-46.

2. Soewarno S. Pengaruh senam pencegahan osteoporosis terhadap kepadatan mineral tulang pada perempuan usia 25-35 tahun, (tesis). Jakarta FKUI, 2001: 43-84.

3. Bongguk R. Pengaruh Depot Medroksi Progesteron Asetat, Estradiol Cypionat dan kalsium pada densitas tulang pasca oophorektomi bilateral, (tesis). Jakarta FKUI, 1998: 4-15.

4. Product monographi. Allovel. The first Priority for Osteoporosis Prevention and Treatment, 2000: 1-14.

5. Winarno B. Densitas Mineral Tulang Wanita Menyusui, (tesis). Jakarta FKUI, 1998: 4-17.

6. Santoso B. Manfaat Raloksifen terhadap perubahan Densitas Mineral Tulang lumbal pada wanita pasca menopause, (tesis) Jakarta FKUI, 2001:6-16.

7. Setyohadi B.The Role of Calcium and vitamin D on Bone metabolism dalam : Simposium Advance Management of Osteoporosis : Prevention, Treatment and Diagnosis. Perosi. Jakarta. Menara Peninsula Hotel, 2001: 12-16.

8. Dharmasetiawan MS. Peranan Pengobatan Hormonal Pengganti Pada Massa Klimakterium. RSPAD Gatot Subroto, Jakarta, 1996: 1-16.

9. Baziad A, Hestiantora A, Rachman IA. Pengobatan \& Pencegahan Osteoporosis dengan Terapi Hormon Pengganti pada Wanita Menopause. Dalam: Panduan Menopause. Ed.I.POGI, PERMI. Jakarta 1997: 44-51.

10. Kanis JA, Devogelaer J-P, Gennari C. Bone Density measurement in the assesment and treatment of osteoporosis : Practical Guidelines. European Foundation For Osteoporosis and bone disease (EFFO) Black Nell Healthcare Ltd. London.1997: 1-12.

11. Limpaphayom K. Osteoporosis: Background, Pathogenesis, Measurement of Bone Density, Prevention and Treatment. Dalam : First Consensus meeting on menopause in the East Asian Region Proceedings. Geneva 1997. $2^{\text {nd }}$ Ed.Medical Forum Internasional BV.1998: 81-94.

12. Pawitan J.A Phytoestrogens : Protection Against a wide Range of Diseases, dalam : Medical progress. 2002: 29: 1: 9-13.

13. Christiansen C. Menopausal Osteoporosis : Impact of Sex Steroid Replacement, dalam Reproductive Endocrinology, Surgery and Technology Vol.2 Lippincoff-Raven Publishers Philadelphia 1996 : 1825-1839

14. Speroff L, Glass RH, Kase NG. Menopause and The Perimenopausal Transition. Dalam: Clinical Endocrinologic and Infertility. $6^{\text {th }}$ ed. Lippincott Williams \& Wilkins.1999. Baltimore: 643-707.

15. Foster G.V. Osteoporosis. Dalam : Decision Making in Reproductive Endocrinology. Black Nell Scientific Publications. Oxford.1993 : 600-605.

16. Jaffe R. The Menopause and perimenopausal period. Dalam : Reproductive Endocrinology 3 rd ed.WB Saunders Company.Philadelphia.1991: 389-405. 
